DOI: https://doi.org/10.34883/PI.2021.9.4.006

UDC 613.96-055.25:616-008.9:616.379-008.64

Tsodikova O. ${ }^{1}$, Harbar K. ${ }^{2}$

${ }^{1}$ Kharkiv International Medical University, Kharkiv, Ukraine

${ }^{2}$ Kharkiv Medical Academy of Postgraduate Education, Kharkiv, Ukraine

Цодикова О.А. ', Гарбар Е.Б. ${ }^{2}$

${ }^{1}$ Харьковский международный медицинский университет, Харьков, Украина

${ }^{2}$ Харьковская медицинская академия последипломного образования, Харьков, Украина

\title{
Problematic Issues of Insulin Resistance in Adolescencent Girls with Body Mass Index Disorders
}

\author{
Проблемные вопросы инсулинорезистентности у девочек \\ подросткового возраста с нарушениями индекса массы тела
}

\begin{abstract}
Introduction. Obesity is recognized as the most important factor leading to the formation of insulin resistance. In clinical practice, insulin resistance is also found in persons with normal body weight. The study of carbohydrate metabolism in case of body mass index disorders has special relevance in adolescence, since sexual development is accompanied by decrease of insulin sensitivity and formation of the so-called pubertal insulin resistance.
\end{abstract}

Purpose. The goal is to study the glycemic status in adolescent girls, taking into account the body mass index and the stage of puberty.

Materials and methods. 124 girls of 8-15 years old have been examined. They were distributed into observation groups, according to the results of calculating the body mass index (BMI), according to the SDS criteria: underweight, overweight/obese, and normal body weight. In order to identify disorders of carbohydrate metabolism in the observation groups, the level of glucose and immunoreactive insulin was determined, and the index of insulin resistance was calculated.

Results. There were no significant differences between the groups in the content of glucose in the blood serum. The number of girls whose insulin levels exceeded physiological values was the highest in the overweight/obese group (59.3\%). Significantly fewer girls with hyperinsulinemia were found in groups with underweight and normal body weight ( $21.4 \%$ and $25.9 \%$, respectively). Increase of the average indices of the HOMA-IR index was noted as the body mass increased. It was revealed that regardless of the parameters of body weight in the prepubertal and early pubertal periods, the level of functional systems tension increases, which is associated with specific features of growth and development that affect the formation of preadaptive characteristics of the organism.

Conclusions. The presence of hyperinsulinemia in adolescent girls with altered body weight, even in the presence of normoglycemia, completely justifies early preventive measures, taking into account the age and individual typological characteristics of the organism.

Linking of this work with scientific programs, plans, themes. The article is a fragment of the research work of the Department of Polyclinic Pediatrics of the KhMAPE «Social, medical-biological and clinical aspects of health formation in the childhood: prognosis - early diagnostics - prevention of chronic somatic pathology» (state registration number 0111 U003590).

Keywords: girls, puberty, body mass index, insulin resistance, carbohydrate metabolism. 
Введение. Ожирение признано важнейшим фактором, приводящим к формированию инсулинорезистентности. В клинической практике инсулинорезистентность обнаруживают и у лиц с нормальной массой тела. Изучение углеводного обмена при нарушениях индекса массы тела приобретает особую актуальность в подростковом возрасте, поскольку половое развитие сопровождается снижением инсулиновой чувствительности с формированием так называемой пубертатной инсулинорезистентности.

Цель. Изучить гликемический статус у девочек подросткового возраста с учетом индекса массы тела и стадии пубертата.

Материалы и методы. Обследовано 124 девочки в возрасте 8-15 лет, которые были распределены в группы наблюдения по результатам расчета индекса массы тела согласно критериям SDS: с дефицитом массы тела, с избыточной массой тела / ожирением и с нормальной массой тела. С целью выявления нарушений углеводного обмена в группах наблюдения определяли уровень глюкозы, иммунореактивного инсулина, рассчитывали индекс инсулинорезистентности.

Результаты. По содержанию глюкозы в сыворотке крови достоверных различий между группами обнаружено не было. Количество девочек, у которых уровень инсулина превышал физиологические значения, было наибольшим в группе с избыточной массой тела / ожирением (59,3\%). Значительно меньше девочек с гиперинсулинемией обнаружено в группах с дефицитом массы тела и нормальной массой тела (21,4\% и $25,9 \%$ соответственно). Увеличение средних показателей индекса HOMA-IR отмечалось по мере возрастания показателей массы тела девочек-подростков. Установлено, что независимо от параметров массы тела в препубертатном и раннем пубертатном периодах повышается уровень напряженности функциональных систем, что связано со специфическими особенностями роста и развития, которые влияют на формирование преадаптивных особенностей организма.

Выводы. Наличие гиперинсулинемии у девочек-подростков с измененной массой тела, даже при наличии нормогликемии, вполне оправдывает проведение ранних профилактических мероприятий с учетом возрастных и индивидуально-типологических особенностей организма.

Связь работы с научными программами, планами, темами. Статья является фрагментом научно-исследовательской работы кафедры поликлинической педиатрии ХМАПО «Соціальні, медико-біологічні та клінічні аспекти формування здоров'я у дитячому віці: прогнозування рання діагностика - профілактика хронічної соматичної патології» (государственный регистрационный номер 0111 U003590).

Ключевые слова: девочки, пубертат, индекс массы тела, инсулинорезистентность, углеводный обмен.

\section{- INTRODUCTION}

Sexual development is an integral part of the girl's puberty, as a period of physiological and psychological changes that helps to adapt to independent living physically and socially. The process of puberty changes is staged, which is based on a strict cyclic interaction of hypothalamic structures, pituitary gland and gonads, which is associated with the girls reproductive system formation.

Factors influencing a girl's puberty period include quality of nutrition, physical and emotional stress, as well as social environment $[3,10,15]$. Deviation of body weight in one or other direction can have a negative impact on the sexual development of adolescents [4]. 
WHO experts recommend the use of body mass index (BMI) for physical development screening assessment, diagnosis of both underweight and overweight, determining the risk of various diseases. Body mass index (BMI), is recognized as one of the most important indicators of physical development [17]. High rates of BMI are associated with obesity, metabolic disorders, cardiovascular disease (CVD), diabetes mellitus (DM), and low rates show protein-energy deficiency, menstrual cycle disorders and the synthesis of sex hormones in girls, further development of gynecological diseases and obstetric complications in them $[8,13,16]$.

Not pronounced excess body weight (EBW) or body weight deficiency (BWD), which does not exceed $10-19 \%$ of the reference values, tend to remain out of the attention of doctors, parents and teachers. However, a large number of adolescents with EBW need medical monitoring to prevent obesity, CVD of atherogenic genesis, hormonal disorders [5, 7, 9, 11, 18]. Very few references have been found in the scientific literature, with regard to BWD, this fact should also attract the attention of experts in order to prevent reproductive health disorders in women since childhood.

Sexual development is accompanied by decrease in insulin sensitivity and the formation of so-called puberty insulin resistance (IR) and increase in insulin levels, causing widespread of metabolic disorders in adolescents $[12,19]$. In the period of puberty in conditions of constant restructuring of hypothalamic structures functioning and changes in rhythm and volume of hormone secretion, autonomic activity of IR, hyperinsulinemia (HI) and hypersympathicotonia mutually potentiate, also activating the mechanisms that contribute to the formation of metabolic syndrome (MS) $[1,2,6,14,20]$.

Therefore, it is important to study the peculiarities of metabolism, in particular carbohydrates, in contemporary adolescent girls having weight disorders (overweight and underweight) at the stage of outpatient monitoring, which is the subject of the study.

The number of scientific works devoted to the study of metabolism peculiarities in contemporary adolescent girls having weight disorders (overweight and underweight) at different stages of puberty is extremely limited, and became the subject of this study.

\section{- PURPOSE OF THE STUDY}

Is to study the adolescent girls glycemic status, taking into account the body mass index and puberty stage.

\section{- MATERIALS AND METHODS}

124 girls aged 8-15 years have been examined. They were distributed into groups for monitoring the results of the body mass index (BMI) according to the criteria (SDS - standard deviation score): the $1^{\text {st }}$ group having body mass deficiency (BMD) -40 children, the $2^{\text {nd }}$ group - having excess body weight/obesity (EBW/O) -42 children, the $3^{\text {rd }}$ group - having normal body weight (NBW) -42 children.

The level of sexual development (SD) was determined according to W.A. Marshal, J.M. Tanner. Therefore, adolescents were distributed into the following subgroups: the first subgroup (prepubertate, PP) - children aged 8-11 years with no secondary sexual characteristics (SSC); the second subgroup (early puberty, EP) - adolescents aged 10-13 years, whose SD 
level corresponded to II-III stages according to Tanner; in the third subgroup (actual puberty, AP) there were teenagers aged 14-15 years whose SD level corresponded respectively to IV-V stages according to Tanner.

In order to detect early carbohydrate metabolism disorders in adolescent girls, glycemic status was determined in terms of fasting glucose and insulin levels index, using a standard glucose tolerance test based on the HOMA-IR cardiac insulin resistance index and the area under the glucose curve. Glucose levels were studied on a biochemical analyzer «Statfax 1904» (USA); level of immunoreactive insulin (IRI) was determined by the method of immunoenzyme analysis (IEA) on the analyzer "Stat Fax 303 Plus» (USA) with sets of reagents DRG (USA). The calculation of the HOMA-IR index (Homeostasis Model Assessment of Insulin Resistance) was performed according to the formula: fasting insulin $(\mathrm{mcU} / \mathrm{ml}) \times$ fasting glucose $(\mathrm{mmol} / \mathrm{L}): 22.5$.

Clinical and statistical methods based on variational statistics, probability distribution of signs and methods of estimating the probability of the obtained results have been used in the study. The average values of indicators and their errors were determined by the formula of the average value of relative indicators.

The degree of probable difference between the mean values was determined using Student's $t$ criterion. The difference between the mean values of the two groups was considered probable at $t \geq 2$, which corresponds to a high level of results reliability (over $95.0 \%$ ) and a high level of probability $(p<0.05)$.

\section{- RESULTS AND DISCUSSION}

It was found that the median and interquartile range of fasting glucose level in the group of girls having BMD (4.7 mmol/L [4.3-5.3]) differed reliably from girls having EBW/O (4.4 mmol/L [3.5-5.8]) and NBW (4.3 mmol/L [3.74.8]). Among girls having EBW/O the interquartile range of this indicator was a bit wider, but the parameters were in line with the age norm.

The median glucose level was reliably higher in the $\mathrm{I}^{\text {st }}$ observation group (in girls having BMD) compared with the II $^{\text {nd }}(E B W / O)$ and the IIIrd $(N B W)$ groups $(p<0.05)$; no reliable differences were found between groups II and III ( $p>0.05)$. When studying of glucose levels, taking into account the degree of obesity, there was a tendency of increasing this indicator as the body mass index increases: it was the $\mathrm{II}^{\text {nd }}$ group where there was one case of hyperglycemia (in the presence of grade 2 obesity, $\mathrm{BMI}=35.8$ ).

According to the results of the research, based on a survey of 372 children at different stages of puberty, the average values of insulin resistance were proposed and it was concluded that their values progressively increase as a teenager matures. We also analyzed the features of carbohydrate metabolism in the observation groups at different stages of puberty: in prepuberty (PP), early puberty (EP) and actual puberty (AP).

There were no reliable differences between the subgroups in the serum glucose content (table 1).

Analyzing the level of insulin in the observation groups, we established the median and interquartile range of its values: $B M D-22.9 \mathrm{mclU} / \mathrm{ml}[14.2$; 31.8], ENW/O - $36.5 \mathrm{mclU} / \mathrm{ml}[5.0 ; 127.1]$, NBW - $20.5 \mathrm{mclU} / \mathrm{ml}$ [2.2; 42.6].

The average insulin values in girls having BMD and NBW did not differ reliably: $22.9 \pm 0.9 \mathrm{mclU} / \mathrm{ml}$ and $20.5 \pm 2.0 \mathrm{mclU} / \mathrm{ml}(\mathrm{p}>0.05)$, but a high degree 
Table 1

Serum glucose content in adolescent girls taking into account BMI and stage of sexual development

\begin{tabular}{|c|c|c|c|c|}
\hline \multirow{2}{*}{$\begin{array}{l}\text { Observation } \\
\text { groups }\end{array}$} & \multicolumn{3}{|c|}{$\begin{array}{l}\text { Division into subgroups depending on the stage of sexual } \\
\text { development }(\mathrm{M} \pm \mathrm{m}), \mathrm{mmol} / \mathrm{L}\end{array}$} & \multirow{2}{*}{$\mathbf{p}$} \\
\hline & $\begin{array}{l}\text { prepuberty, } \\
n=17\end{array}$ & $\begin{array}{l}\text { early puberty, } \\
n=29\end{array}$ & $\begin{array}{l}\text { actual puberty, } \\
n=25\end{array}$ & \\
\hline BMD & $4.5 \pm 0.1$ & $4.8 \pm 0.1$ & $4.3 \pm 0.1$ & $\begin{array}{l}a-b>0.05 \\
a-c>0.05 \\
b-c>0.05\end{array}$ \\
\hline EBW/O & $4.6 \pm 0.3$ & $4.2 \pm 0.2$ & $4.5 \pm 0.2$ & $\begin{array}{l}a-b>0.05 \\
a-c>0.05 \\
b-c>0.05\end{array}$ \\
\hline NBW & $4.3 \pm 0.1$ & $4.6 \pm 0.1$ & $4.2 \pm 0.1$ & $\begin{array}{l}a-b>0.05 \\
a-c>0.05 \\
b-c>0.05\end{array}$ \\
\hline
\end{tabular}

Notes: a - prepuberty; b - early puberty; c - actually puberty.

of differences was found in comparison with EBW/O group, where the value is $36.5 \pm 5.4 \mathrm{mclU} / \mathrm{ml}(p<0,001)$.

The number of girls whose insulin levels exceeded physiological values was the highest in group II (59.3\%), lower - in groups I and III $(21.4 \%$ and $25.9 \%$ ). The presence of $\mathrm{HI}$ in normoglycemia, as a rule, indicates insulin resistance, which is a precursor to the development of type 2 diabetes. Today, it is proven that obesity is the most important factor leading to the formation of insulin resistance (IR). Many researchers have found a close correlation between an increase in waist volume, which indicates the presence of abdominal obesity, and the severity of IR. However, in some cases, IR is observed in people with normal body weight, in the absence of abdominal obesity. There is an assumption that in such patients the decrease in tissue sensitivity to insulin is genetically programmed.

One of the most interesting theories is the hypothesis of the relationship of IR with low body weight of children at birth. It is assumed that malnutrition of the fetus in utero leads to a persistent violation of tissue sensitivity to insulin, the tendency to obesity in adulthood, and subsequently leads to the formation of other manifestations of MS. In this regard, we carefully studied the medical records and found that prematurity at birth was probably more common among children having EBW/O (21.4 $\pm 6.35 \%)$ compared to children having BMD $(5.0 \pm 3.4 \%)$ and NBW $(4.8 \pm 3.3 \%)(p<0.05)$.

Insulin threshold levels, according to various authors, are in the range of $11.0-20.0 \mathrm{mclU} / \mathrm{ml}$ (in clinical practice, the range of $11.0-15.3 \mathrm{mclU} /$ $\mathrm{ml}$ is more often used). The presence of hyperinsulinemia in the group of girls having NBW and BMD can be considered as compensation necessary to overcome IR and maintain normal glucose transport into cells. Since insulin can affect a variety of metabolic processes, in adolescent girls in this case, it synchronizes the processes of growth and puberty with the optimal level of metabolism in the body. The values of IR indicators progressively increase during puberty. In obese girls, this factor can be pathological and contribute to the emergence and development of metabolic, hemodynamic and organ disorders, which lead to the development of type 2 diabetes and dyslipidemia. 
Table 2

Serum insulin content in adolescent girls taking into account BMI and stage of sexual development

\begin{tabular}{|c|c|c|c|c|}
\hline \multirow{2}{*}{$\begin{array}{l}\text { Observation } \\
\text { groups }\end{array}$} & \multicolumn{3}{|c|}{$\begin{array}{l}\text { Division into subgroups depending on the stage of sexual } \\
\text { development }(\mathrm{M} \pm \mathrm{m}), \mathrm{mclU} / \mathrm{ml}\end{array}$} & \multirow{2}{*}{$\mathbf{p}$} \\
\hline & $\begin{array}{l}\text { prepuberty, } \\
n=17\end{array}$ & $\begin{array}{l}\text { early puberty, } \\
\mathrm{n}=29\end{array}$ & $\begin{array}{l}\text { actually puberty, } \\
\mathrm{n}=\mathbf{2 5}\end{array}$ & \\
\hline BMD & $14.2 \pm 0.2$ & $25.3 \pm 9.8$ & $22.1 \pm 1.1$ & $\begin{array}{l}a-b<0.05 \\
a-c<0.05 \\
b-c>0.05\end{array}$ \\
\hline EBW/O & $34.2 \pm 9.8$ & $37.2 \pm 10.9$ & $36.4 \pm 10.1$ & $\begin{array}{l}a-b>0.05 \\
a-c>0.05 \\
b-c>0.05\end{array}$ \\
\hline NBW & $14.2 \pm 1.1$ & $21.5 \pm 4.3$ & $27.3 \pm 5.6$ & $\begin{array}{l}a-b<0.05 \\
a-c<0.05 \\
b-c<0.05\end{array}$ \\
\hline
\end{tabular}

Notes: $a$ - prepuberty; b - early puberty; c - actually puberty.

In PP, EP and AP, the average insulin levels in the entire sample tended to increase in values as the girls' body matured (table 2).

It is interesting to find a reliable increase in the average insulin levels among girls of the llnd group having the presence of obesity of the 1st and the 2nd degrees $(33.3 \pm 4.2 \mathrm{mclU} / \mathrm{ml}$ and $67.9 \pm 5.4 \mathrm{mclU} / \mathrm{ml})$ compared to those BMD and NBW $(22.9 \pm 0.9 \mathrm{mclU} / \mathrm{ml}$ and $20.5 \pm 2.0 \mathrm{mclU} / \mathrm{ml})(p<0.001)$. However, the lower level of this indicator in $1 / 3$ girls of group II $(8.5 \pm 0.9$ $\mathrm{mclU} / \mathrm{ml})$ in comparison with the group having BMD and NBW $(p<0.001)$ remains unclear.

Insulin levels in girls having EBW/O, while remaining consistently high at all stages of sexual development, tended to increase at the stage of early puberty, in the absence of significant differences ( $p>0.05)$. In girls having $B M D$ at the stage of early puberty there was a sharp rise in the rate (from $14.2 \pm 0.2$ to $25.3 \pm 9.8 \mathrm{mcm} / \mathrm{l}$ ) and a slight decrease until the end of puberty $(22.1 \pm 1.1 \mathrm{mcm} / \mathrm{l})$. In girls having BMD there was a gradual increase in insulin levels in prepuberty $(14.2 \pm 1.1 \mathrm{mcm} / \mathrm{l})$, in early puberty $(21.5 \pm 4.3 \mathrm{mcm} / \mathrm{l})$ and until the end of puberty $(27.3 \pm 5.6 \mathrm{mcm} / \mathrm{l})$.

The calculation of the HOMA-IR index in the observation groups revealed a range of its values in all groups. Reliability of differences in averages was found between groups I and II, II and III ( $p<0.05)$.

The median and interquartile range of index values in the observation groups had the following parameters: BMD - 4.7 [2.9; 6.7], EBW/O - 6.5 [2.8; $16.2]$, NBW $-5.2[0.4 ; 19.7]$. The frequency of exceeding the standards of this indicator in the observation groups was different: $14.2 \%$ among girls having BMD, 31.2\% - ones having EBW/O and $29.6 \%$ - ones having NBW.

There was found a pattern - the average values of the HOMA-IR index increased with increase of the girls' body weight (4.6 \pm 0.8 in BMl; $9.2 \pm 0.8$ in the $1^{\text {st }}$ degree obesity and $10.2 \pm 0.8$ in the $2^{\text {nd }}$ degree obesity).

During puberty, the whole sample tended to increase the values of the HOMA-IR index: $4.2 \pm 0.5$ in prepuberty, $5.7 \pm 0.7$ in early puberty and $6.6 \pm 0.7$ at the stage of actual puberty (Table 3 ). 
Table 3

Serum NOMA-IR levels in the adolescent girls taking into account BMI and stage of sexual development

\begin{tabular}{|c|c|c|c|c|}
\hline \multirow{2}{*}{$\begin{array}{l}\text { Observation } \\
\text { groups }\end{array}$} & \multicolumn{3}{|c|}{$\begin{array}{l}\text { Division into subgroups depending on the stage of sexual } \\
\text { development }(\mathrm{M} \pm \mathrm{m})\end{array}$} & \multirow{2}{*}{$\mathbf{p}$} \\
\hline & $\begin{array}{l}\text { prepuberty, } \\
n=17\end{array}$ & $\begin{array}{l}\text { early puberty, } \\
\mathrm{n}=29\end{array}$ & $\begin{array}{l}\text { actually puberty, } \\
\mathrm{n}=\mathbf{2 5}\end{array}$ & \\
\hline BMD & $2.9 \pm 0.1$ & $5.4 \pm 0.4$ & $4.2 \pm 0.8$ & $\begin{array}{l}a-b<0.05 \\
a-c<0.05 \\
b-c>0.05\end{array}$ \\
\hline EBW/O & $6.4 \pm 1.7$ & $6.5 \pm 1.5$ & $6.1 \pm 1.3$ & $\begin{array}{l}a-b>0.05 \\
a-c>0.05 \\
b-c>0.05\end{array}$ \\
\hline NBW & $2.8 \pm 0.2$ & $5.5 \pm 1.6$ & $8.2 \pm 2.2$ & $\begin{array}{l}a-b<0.05 \\
a-c<0.05 \\
b-c<0.05\end{array}$ \\
\hline
\end{tabular}

Notes: a - prepuberty, b - early puberty, c - actually puberty.

Sharp increase of an indicator at a stage of early puberty was revealed in adolescent girls having BMD and NBW; a slight decrease before the completion of puberty was observed in girls having BMD; indicators were within the previous values in girls having EBW/O.

Insulin levels have been analyzed in the observation groups and the median (Me) and interquartile range of values ( $\mathrm{Lq}$ - lower quartile, Uq upper quartile) have been determined: for BMD - $22.9 \mathrm{mclU} / \mathrm{ml}[14.2 ; 31.8]$, for EBW/O - $36.5 \mathrm{mclU} / \mathrm{ml}$ [5.0; 127.1], for NBW - $20.5 \mathrm{mclU} / \mathrm{ml}[2.2 ; 42.6]$. The number of girls whose insulin levels exceeded physiological values was the highest in the $2^{\text {nd }}$ group (59.3\%), lower - in the $1^{\text {st }}$ and $3^{\text {rd }}$ groups $(21.4 \%$ and $25.9 \%)(p<0.05)$.

Threshold levels of insulin, according to various authors, are within the rangeof $11.0-20.0 \mathrm{mclU} / \mathrm{ml}$ (morecommonlyusedonesare 11.0-15.3 $\mathrm{mclU} / \mathrm{ml}$ ). It can be assumed that $\mathrm{HI}$ in the group of girls having NBW and BMD performs a compensatory function which is necessary to overcome IR and maintain normal glucose transport into cells. Since insulin affects a variety of metabolic processes, in this very case it can synchronize the processes of growth and puberty with the optimal level of metabolism in the body.

Insulin levels in girls having EBW/O remained consistently high at all stages of $S D$ and increased at the stage of EP, in the absence of significant differences in its content at the stages of PP and AP ( $p>0.05)$. In girls having BMD at the stage of EP there was a sharp increase (from 14.2 \pm 0.2 to $25.3 \pm 9.8 \mathrm{mclU} / \mathrm{ml}$ ) and its slight decrease before puberty completion $(22.1 \pm 1.1 \mathrm{mclU} / \mathrm{ml}))$. At NBW there was a gradual increase in insulin levels in PP $(14.2 \pm 1.1 \mathrm{mclU} / \mathrm{ml})$, then - in EP $(21.5 \pm 4.3 \mathrm{mclU} / \mathrm{ml})$ and at the stage of formation of AP $(27.3 \pm 5.6 \mathrm{mclU} / \mathrm{ml})(\mathrm{p}>0.05)$.

The credibility of differences in the average indicators of the HOMA-IR index was found between the $1^{\text {st }}$ and $2^{\text {nd }}$ and $2^{\text {nd }}$ and $3^{\text {rd }}$ groups $(p<0.05)$. The median and interquartile range of HOMA-IR index values in the groups were: for BMD - 4.7 [2.9; 6.7], for EBW/O - 6.5 [2.8; 16.2], for NBW - 5.2 [0.4; 19.7]. The percentage of adolescents who exceeded the HOMA-IR reference values in the observation groups was different: $14.2 \%$ among girls 
having BMD, 31.2\% - ones having EBW/O and 29.6\% - ones having NBW; the probability of differences was found between the $1^{\text {st }}$ and $3^{\text {rd }}$ groups $(p<0.05)$. The increase in the average index indicators was observed in girls having increasing BM ( $4.6 \pm 0.8$ with EBW/O; $9.2 \pm 0.8$ having obesity of the ${ }^{\text {st }}$ stage and $10.2 \pm 0.8$ having obesity of the IInd stage $P<0.05)$. The presence of $B M D$ and NBW revealed a sharp rise of the indicator at the stage of EP and a slight decrease at the stage of AP; at EBW/O - the indicator was within the reference values.

\section{CONCLUSIONS}

1. Analysis of insulin levels in adolescent girls at different stages of puberty showed that regardless of body weight parameters in prepuberty and early puberty periods the level of tension of functional systems increases, which is associated with specific features of growth and development that affect the formation of preadaptive features of teenage girls' body.

2. The presence of hyperinsulinemia in adolescent girls with altered body weight (59.3\% having EBW/O and $21.4 \%$ having BMD), even in the presence of normoglycemia fully justifies the implementation of early preventive measures, taking into account age and individual typological features of the body, aimed at the prevention of hyperinsulinism and premature atherogenesis.

3. The study of the vegetative homeostasis characteristics in adolescent girls should be considered promising, taking into account BMI and puberty stage.

Conflict of interest. The authors declare no conflict of interest.

\section{REFERENCES}

1. Bokova T.A. (2018) Factory riska formirovaniya metabolicheskogo sindroma u detej s ozhireniem [Risk factors for metabolic syndrome in obese children]. Rossiyskiy Vestnik Perinatologii i Pediatrii, vol. 63(3), pp. 64-69. Available at: https://doi.org/10.21508/1027-4065-2018-63-3-64-69

2. Dania Al-Hamad, Vandana Raman (2017) Metabolic syndrome in children and adolescents. Translational Pediatrics, vol. 6, no 4, pp. $397-407$. DOI: $10.21037 /$ tp.2017.10.02

3. Dianne Neumark-Sztainer, Melanie M Wall, Chen Chen (2018) Eating, activity, and weight-related problems from adolescence to adulthood. American journal of preventive medicine, vol. 55(2), pp. 133-141. DOI: 10.1016/j.amepre.2018.04.032

4. Dong Wook Kim, Junghwan Suh, Ah Reum Kwon, Hyun Wook Chae (2018) Visceral fat thickness and its associations with pubertal and metabolic parameters among girls with precocious puberty. Annals of Pediatric Endocrinology \& Metabolism, vol. 23(2), pp. 81-87. Available at: https://doi. org/10.6065/apem.2018.23.2.81

5. Elin Evensen, Tom Wilsgaard, Anne-Sofie Furberg, Guri Skeie (2016) Tracking of overweight and obesity from early childhood to adolescence in a population-based cohort - the Tromsø Study, Fit Futures. BMC Pediatr., vol. 16, p. 64. Available at: https://doi.org/10.1186/s12887-016-0599-5

6. Fateme Hooshmand, Golaleh Asghari, Emad Yuzbashian, Maryam Mahdavi (2018) Modified healthy eating index and incidence of metabolic syndrome in children and adolescents: Tehran lipid and glucose study. J Pediatrics, vol. 197, pp. 134-139. DOI: 10.1016/j.jpeds.2018.01.080

7. Haji Chomba, Haikael D. Martin, Judith Kimywe (2019) Prevalence and Predictors of Obesity among 7-to 17-Year-Old Schoolchildren in Urban Arusha, Tanzania. Journal of Nutrition and Metabolism, vol. 2019(1), pp. 1-11. Available at: https://doi.org/10.1155/2019/3106597

8. Jens Jordan, Andreas L Birkenfeld (2016) Cardiometabolic crosstalk in obesity-associated arterial hypertension. Rev Endocr Metab Disord., vol. 17(1), pp. 19-28. DOI: 10.1007/s11154-016-9348-1

9. Maria Lucia Specchia, Andrea Barbara, Paolo Campanella, Paolo Parente (2018) Highly-integrated programs for the prevention of obesity and overweight in children and adolescents: results from a systematic review and meta-analysis. Ann Ist Super Sanita., vol. 54(4), pp. 332-339. DOI: 10.4415/ANN_18_04_10

10. Małgorzata Mizgier, Grażyna Jarząbek-Bielecka, Justyna Opydo-Szymaczek (2020) Risk factors of overweight and obesity related to diet and disordered eating attitudes in adolescent girls with clinical features of polycystic ovary syndrome. Journal of Clinical Medicine, vol. 9(9), p. 3041. DOI: $10.3390 / \mathrm{jcm} 9093041$

11. Markus Juonala, Ted Lau, Melissa Wake, Anneke Grobler (2020) Early clinical markers of overweight/obesity onset and resolution by adolescence. International Journal of Obesity, vol. 44(1), pp. 82-93. DOI: 10.1038/s41366-019-0457-2 
12. Megan M Kelsey, Philip S Zeitler (2016) Insulin resistance of puberty. Current Diabetes Reports, vol. 16(7), p. 64. DOI: 10.1007/s11892-016-0751-5

13. Nicole Prinz, Anke Schwandt, Marianne Becker, Christian Denzer, Monika Flury et al. (2018) Trajectories of body mass index from childhood to young adulthood among patients with type 1 diabetes - a longitudinal group-based modeling approach based on the DPV registry. The Journal of Pediatrics, vol. 201, pp. 78-85. DOI: 10.1016/j.jpeds.2018.05.014

14. Nunes J.M., Medina J.L., Santos A.C. et al. (2017) Obesity and metabolic syndrome in children: what's new? Endocrinology \& Metabolism International Journal, vol. 4, no 3, pp. 79-81. DOI: 10.15406/emij.2017.04.00090

15. Phoebe Dalwood, Skye Marshall, Tracy L. Burrows (2020) Diet quality indices and their associations with health-related outcomes in children and adolescents: an updated systematic review. Nutrition Journal, vol. 19 (1), article number: 118. DOI: 10.1186/s12937-020-00632-x

16. SusannWeihrauch-Blüher, Susanna Wiegand (2018) Risk factors and implications of childhood obesity. Current Obesity Reports, vol. 7(4), pp. 254-259. DOI: 10.1007/s13679-018-0320-0

17. Tsodikova O.A., Krilova O.B., Rognov O.O., Harbar K.B. et al. (2017) Osoblivosti fizichnogo rozvitku ta statevogo dozrivannya divchatok pidlitkovogo viku zalezhno vid indeksu masi tila [Peculiarities of physical development and puberty of adolescent girls depending on body mass index]. Visnik Vinnic'kogo nacional'nogo medichnogo universitetu, vol. 21, no 1(2), pp. 227-230. Available at: http://nbuv.gov.ua/UJRN/ vvnmu_2017_21_1(2)_8

18. US Preventive Services Task Force, David C Grossman, Kirsten Bibbins-Domingo, Susan J Curry et al. (2017) Screening for obesity in children and adolescents: US preventive services task force recommendation statement. JAMA, vol. 317(23), pp. 2417-2426. DOI: 10.1001/jama.2017.6803

19. Veronica Maria Tagi, Cosimo Giannini, Francesco Chiarelli (2019) Insulin Resistance in Children. Frontiers in Endocrinology (Lausanne), vol. 10, p. 342. DOI: $10.3389 /$ fendo.2019.00342

20. Zaharova I.N., Malyavskaya S.I., Tvorogova T.M. (2016) Metabolicheskij sindrom u detej i podrostkov opredelenie. Kriterii diagnostiki [Definition of metabolic syndrome in children and adolescents. Diagnostic criteria]. Medicinskij Sovet, vol. 16, pp. 103-109. Available at: https://doi. org/10.21518/2079-701X-2016-16-103-109

Submitted/Подана: 04.04.2021

Accepted/Принята: 22.11.2021

Contacts/Контакты: tsodikova.olga@gmail.com

The article is published in the author's edition. 